\title{
Ferromagnetic Activated Carbon from Cassava (Manihot dulcis) Peels Activated by Iron(III) Chloride: Synthesis and Characterization
}

\begin{abstract}
Gervais Kounou Ndongo, Ndi Julius Nsami,* and Ketcha Joseph Mbadcam
Ferromagnetic activated carbon (FAC) was prepared through impregnation of cassava peel with $\mathrm{FeCl}_{3}(3.75 \%)$ solution and pyrolyzed at $800^{\circ} \mathrm{C}$. Samples were characterized using iodine number, methylene blue number, X-ray fluorescence, Fourier transformation infrared, X-ray diffraction (XRD), scanning electron microscopy (SEM) coupled to energy dispersive X-ray spectroscopy, elemental analysis and $\mathrm{N}_{2}$ adsorption for surface area determination. The proximate analysis of cassava peel showed that the moisture content, fixed carbon, ash content, and the volatile matter were $3.52 \%, 82.97 \%, 4.97 \%$, and $8.54 \%$, respectively. The prepared FAC had a BET surface area of $405.9 \mathrm{~m}^{2} / \mathrm{g}$, pore size of $2.03 \mathrm{~nm}$ and total pore volume of $0.11 \mathrm{~cm}^{3} / \mathrm{g}$. The SEM analysis showed the presence of both micro and mesopores on the FAC sample. The XRD pattern of FAC showed the presence of characteristic peaks of magnetite-maghemite, confirming that the prepared material is ferromagnetic. According to the experimental results, the cassava peels are considered as appropriate raw material for FAC preparation.
\end{abstract}

Keywords: Ferromagnetic; Activated carbon; Chemical activation; Cassava peel; Methylene blue number

Contact information: Applied Physical and Analytical Chemistry Laboratory, Department of Inorganic Chemistry, University of Yaoundé I, Yaoundé, Cameroon;

* Corresponding author: ndinsami2002@yahoo.com

\section{INTRODUCTION}

Activated carbon (AC) is a carbonaceous material most widely used as an adsorbent because of its well-developed pore structure, large active surface area, good mechanical properties, and presence of multiple functional groups at its surface (Kouotou et al. 2013a). It has been used for water treatment, separation, purification, catalysis, energy storage, batteries, fuel cells, nuclear power stations, electrodes for electric double layer capacitors, pharmaceutical purposes, hydrometallurgy, and other applications (Hesas et al. 2013; Mohd et al. 2015).

The most common precursors used for the preparation of commercial AC are coal and lignite, which are non-renewable sources (Ahmedna et al. 2000; Kailappan et al. 2000; Lima and Marshall 2005; Ioannidou and Zabaniotou 2007; Tan et al. 2008; Altenor et al. 2009; Girods et al. 2009; Okibe et al. 2013; Sing et al. 2013). However, the high production costs of these materials tend to be more expensive than other adsorbents. Therefore, researchers have focused on the production of activated carbons from renewable sources such as sugarcane bagasse, coconut shells (Jaguaribe et al. 2005), peanut hull (Guler et al. 2007), rattan sawdust (Hameed et al. 2007a), hazelnut bagasse (Karabacakoğlu et al. 2008), cotton stalk fibre (Kunquan et al. 2009), oil palm shell (Kouotou et al. 2013b), cola nut shell (Ndi and Ketcha 2013) and olive stone (Hanen and 
Abdelmottaleb 2013). The production of AC from these agricultural by-products could have a beneficial effect on the environmental.

The AC preparation includes physical, chemical, or physicochemical activation methods. In the first method, the $\mathrm{AC}$ is obtained after two distinct steps, namely carbonization and activation using $\mathrm{CO}_{2}$ or steam water. The chemical activation method is a single step process with the activation and carbonization at once, where $\mathrm{ZnCl}_{2}$, $\mathrm{H}_{3} \mathrm{PO}_{3}, \mathrm{FeCl}_{3}, \mathrm{KOH}$, and $\mathrm{K}_{2} \mathrm{HPO}_{4}$ are often used as chemical activating agents. In contrast, the combination of chemical and physical activation, at the same time is physicochemical activation (Lékéné et al. 2018).

In Cameroon, an agricultural country, cassava is one of the most important crops. It is more often used as traditional food such as tapioca, cake, etc. (Agbor et al. 1995). In the industrial scale, cassava is used for production of starch. The intensive production of cassava crops leads to a large amount of waste (cassava peel) that is discharged and causes environmental issues (Sudaryanto 2006). One way to valorize these cassava peel (CP) wastes is to convert it into AC. Furthermore, there has been no study related to the preparation of ferromagnetic activated carbon (FAC) based on Cameroonian cassava peel, which entails the novelty of this present work.

\section{EXPERIMENTAL}

\section{Materials}

Preparation of ferromagnetic activated carbon

Cassava tubers were harvested from a local farm in Mbangassina Subdivision, Center Region of Cameroon and were used after peeling. The peels were washed with tap water, sundried, crushed, and sieved to approximately $0.9 \mathrm{~mm}$. The raw material was impregnated with $\mathrm{FeCl}_{3}(3.75 \%)$ and stirred at room temperature for $3 \mathrm{~h}$. The mixture was dried at $110{ }^{\circ} \mathrm{C}$ and then carbonized by pyrolysis at various temperatures $\left(500{ }^{\circ} \mathrm{C}\right.$, $650{ }^{\circ} \mathrm{C}$, and $800{ }^{\circ} \mathrm{C}$ ), with residence time of $2 \mathrm{~h}$ under heating rate of $10{ }^{\circ} \mathrm{C} / \mathrm{min}$ in a carbolite furnace. The carbonized samples were repeatedly washed with distilled water to ensure the removal of excess $\mathrm{FeCl}_{3}$ and oven-dried at $110{ }^{\circ} \mathrm{C}$. The $\mathrm{FAC}$ obtained was crushed, sieved and stored in desiccators for further experiments.

\section{Characterization techniques}

The CP and FAC samples were characterized using several techniques. Proximate analysis was performed using ASTM protocols: ash content according to ASTM D286611 (2011), moisture content according to ASTM D2866-94 (Ndi et al. 2014), volatile matter according to ASTM D5832-98 (2014), and fixed carbon was determined by the percentage difference. The iodine and methylene blue adsorptions were used to test the adsorption capacity of FAC. The iodine number gives the information relative to the microporosity of the material, whereas methylene blue adsorption gives the information on mesoporosity.

Surface morphology was assessed using a SEM (ASPEX 3020; FEI Company, Hillsboro, OR, USA). Samples were deposited on a conductive tab pressed onto a specimen holder and coated with gold under vacuum using a sputter-coater (NANOMASTER, Inc., Austin, TX, USA). The SEM photographs were taken using a scanning electron microscope (Amray 1610 Turbo; Amray Inc., San Jose, CA, USA). The determination of surface area and porosity was performed by means of $\mathrm{N}_{2}$ adsorption- 
desorption experiments using a Micrometrics model sorptometer (Thermo Electron Corporation, Waltham, MA, USA) and their values were calculated using the BrunauerEmmett-Teller (BET) and Barret-Joyner-Halenda (BJH) equation models, respectively. Prior to $\mathrm{N}_{2}$ adsorption, the samples were evacuated at $301.1 \mathrm{~K}$ under vacuum. The surface area was defined from linear part of the BET equation. The elemental contents of $\mathrm{C}, \mathrm{H}$, and $\mathrm{N}$ percentages were determined using a CHNS analyzer (Euro EA 3000; Exeter Analytical Inc., Chelmsford, MA,USA).

The mineral composition of samples was assessed using an X-ray fluorescent (XRF) analyzer (Bruker S2 Pico Fox; HITACHI High-Technology, Krefeld, Germany). A total of $0.05 \mathrm{~g}$ of the sample was ground and mixed with $25 \mathrm{~mL} \mathrm{1vol \%} \mathrm{aqueous} \mathrm{Triton}$ X-100 solution and $10 \mu \mathrm{L}$ of PerkinElmer (PerkinElmer Inc., Waltham, MA, USA) pure arsenic $\left(2 \% \mathrm{HNO}_{3}\right)$ standard solution as an internal standard before completing the analysis.

Fourier-transform infrared spectroscopy (FTIR) spectra were obtained on a Genesis FTIR spectrometer (Mattson Instruments, Inc., Madison, WI, USA) equipped with a DTGS (deuterated tri glycine sulfate) detector in the transmission mode from 400 to $4000 \mathrm{~cm}^{-1}$, after 20 scans, for the material's surface functional groups determination. The X-ray diffraction (XRD) was conducted for crystalline phase identification using a DECTRIS (Paul Scherrer Institute, Baden-Daettwil, Switzerland) instrument with $\mathrm{Cu} \mathrm{K}_{\alpha 1}$ $(\lambda=1.54056 \AA$; Gemonochromator; flat samples) in transmission geometry with a DECTRIS ${ }^{\circ}$ MYTHEN 1K detector. The drift method was used to determine the $\mathrm{pH}$ of zero-point charge (pHzPC) as reported by Lékéné et al. (2018) and Tounsadi et al. (2016).

\section{RESULTS AND DISCUSSION}

\section{Proximate and Ultimate Analysis of CP and FAC}

The proximate and ultimate analysis results of CP and FAC are exhibited in Table 1. From the table, it can be observed that $\mathrm{CP}$ has high fixed carbon $(83.0 \%)$ and low ash content $(4.97 \%)$ implying the presence of relatively little inorganic matter. Moreover, the carbon content of $\mathrm{CP}$ was $39.8 \%$ indicating that it could successfully be used as a good precursor for activated carbon preparation. Similar results were obtained by other authors (Budinova et al. 2006; Ndi et al. 2014). After activation and carbonization process, the carbon content of FAC (70.2\%) was higher compared to that of $\mathrm{CP}(39.8 \%)$. In contrast, the authors observed a noticeable reduction in the other elements $(\mathrm{H}, \mathrm{N}$, and $\mathrm{O})$. This can be explained by the loss of water and volatile mater during the carbonization step (Lékéné et al. 2018).

Table 1. Proximate and Ultimate Composition of CP and FAC

\begin{tabular}{|c|c|c|c|c|c|c|c|c|}
\hline Materials & $\begin{array}{c}\text { Moisture } \\
\text { Content } \\
(\%)\end{array}$ & $\begin{array}{c}\text { Volatile } \\
\text { Matter } \\
(\%)\end{array}$ & $\begin{array}{c}\text { Ash } \\
\text { Content } \\
(\%)\end{array}$ & $\begin{array}{c}\text { Fixed } \\
\text { Carbon } \\
(\%)\end{array}$ & $\begin{array}{c}\mathrm{C} \\
(\%)\end{array}$ & $\begin{array}{c}\mathrm{H} \\
(\%)\end{array}$ & $\begin{array}{c}\mathrm{N} \\
(\%)\end{array}$ & $\begin{array}{c}\mathrm{O} \\
(\%)\end{array}$ \\
\hline CP & 3.52 & 8.54 & 4.97 & 82.97 & 39.85 & 6.19 & 6.19 & 52.22 \\
\hline FAC & - & - & - & - & 70.15 & 2.04 & 0.74 & 27.04 \\
\hline
\end{tabular}




\section{Optimization of FAC Preparation}

To observe the effect of carbonization temperature on the adsorption capacity of FAC and CP, the material was impregnated with $3.75 \% \mathrm{FeCl}_{3}$ solution, the carbonization temperature was varied and the results of adsorption of iodine and methylene blue depicted in Fig. 1.

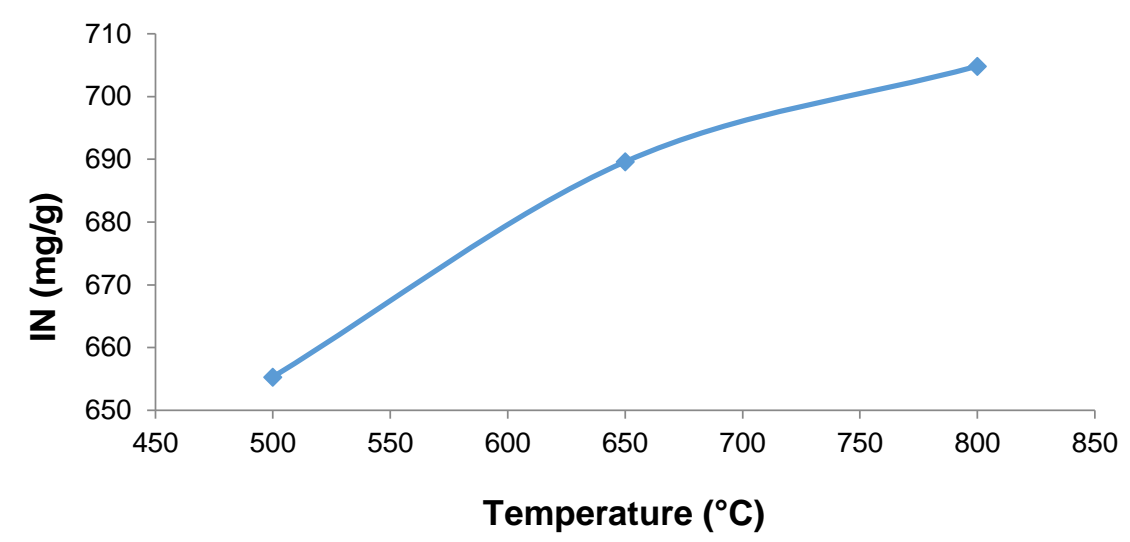

A

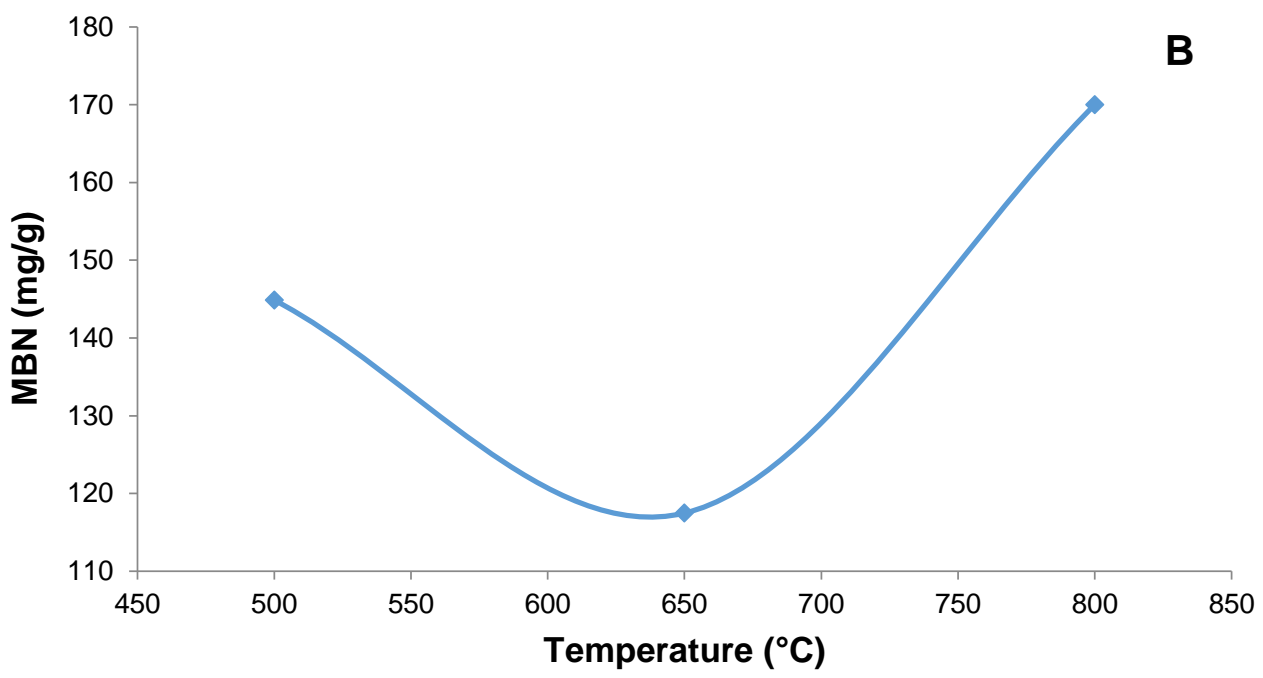

Fig. 1. A) lodine number curve and B) Methylene blue number curve

Figure 1A shows that the IN of FAC increased with increasing carbonization temperature and reached the maximum of $704.8 \mathrm{mg} / \mathrm{g}$ at $800{ }^{\circ} \mathrm{C}$. The increase in iodine adsorption capacity was accredited to the deeper amount of carbon-steamboat reaction, which facilitates the formation of new micropores and well developed pore structure (Duan et al. 2011).

Figure $1 \mathrm{~B}$ presents the decreasing trend of $\mathrm{MBN}$ from 500 to $650{ }^{\circ} \mathrm{C}$. This trend could be due to the fact that in this range, the micropores are mainly formed on the materials surface; methylene blue being a large molecule, the micropores formation is not suitable for methylene blue adsorption. However, the methylene blue number increased with increasing carbonization temperature from 650 to $800{ }^{\circ} \mathrm{C}$. This is attributed to the fact that increase in temperature can develop simultaneously micro- and mesoporous structure, and thus increases adsorption of large molecules such as methylene blue. 
Increase in temperature from 650 to $800{ }^{\circ} \mathrm{C}$ is suitable for the preparation of $\mathrm{AC}$ possessing both micro- and mesoporous structure in this case (Caturla et al. 1991; Hameed et al. 2007b). The FAC possesses developed mesoporous structures as indicated by the maximal methylene blue number adsorbed $(170.0 \mathrm{mg} / \mathrm{g})$. Therefore, it was concluded that FAC contained both mesopores and micropores. These results were in accordance with those of Pelekani and Snoeyink (2000).

The values obtained of iodine number $524.3 \mathrm{mg} / \mathrm{g}$ and methylene blue number $143.2 \mathrm{mg} / \mathrm{g}$ after carbonization at $800{ }^{\circ} \mathrm{C}$ of the $\mathrm{CP}$ without being impregnated with iron chloride (III) are lower than those obtained after impregnation with iron chloride (III) at the same temperature.

\section{EDX analysis of $C P$}

Figure 2 shows the EDX spectrum of CP. This figure displays the presence of carbon, potassium, and oxygen as expected, which matches with that of the results obtained from ultimate results. The $\mathrm{CP}$ is an excellent low-cost precursor for the production of activated carbon, due to the high percentage of carbon that it contains.

$X$-ray Fluorescence of the cassava peel and ferromagnetic activated carbon

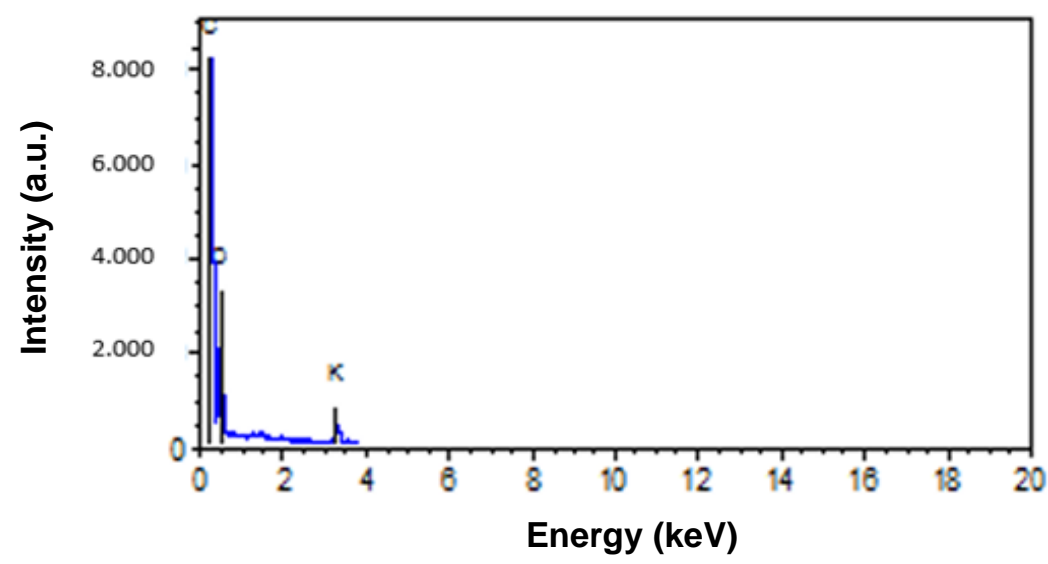

Fig. 2. Energy dispersive $\mathrm{X}$-ray (EDX) spectrum of $\mathrm{CP}$

Table 2. Results from X-ray Fluorescence of CP and FAC

\begin{tabular}{|c|c|c|c|c|c|}
\hline \multirow{2}{*}{ Elements } & \multicolumn{2}{|c|}{ CP } & FAC & \multirow{2}{*}{ Elements } & \multicolumn{2}{c|}{ CP } & FAC \\
\cline { 2 - 3 } & \multicolumn{2}{|c|}{ Percentage (\%) } & & \multicolumn{2}{c|}{ Percentage (\%) } \\
\cline { 5 - 6 } & & & $\mathrm{Cu}$ & 0.09 & 0.04 \\
\hline $\mathrm{Al}$ & 73.20 & 32.51 & $\mathrm{Zn}$ & 0.08 & 0.06 \\
\hline $\mathrm{P}$ & 1.36 & - & $\mathrm{Ga}$ & 0.05 & 0.01 \\
\hline $\mathrm{Cl}$ & 0.16 & - & $\mathrm{As}(\mathrm{IS})$ & 0.06 & 0.03 \\
\hline $\mathrm{K}$ & 4.51 & 4.94 & $\mathrm{Rb}$ & 0.05 & 0.06 \\
\hline $\mathrm{Ca}$ & 0.42 & 0.66 & $\mathrm{Sr}$ & 0.03 & 0.01 \\
\hline $\mathrm{Ti}$ & 9.58 & 4.22 & $\mathrm{~Pb}$ & 0.03 & 0.03 \\
\hline $\mathrm{Cr}$ & 0.16 & 0.11 & $\mathrm{Th}$ & 0.01 & - \\
\hline $\mathrm{Fe}$ & 10.16 & 34.58 & $\mathrm{Zr}$ & - & 21.97 \\
\hline $\mathrm{Mn}$ & - & 0.19 & $\mathrm{Ba}$ & - & 0.54 \\
\hline $\mathrm{Ni}$ & 0.05 & 12.06 & & & \\
\hline
\end{tabular}


Table 2 shows that the aluminum content was high in the form of oxides and specifically as aluminum oxide $\left(\mathrm{Al}_{2} \mathrm{O}_{3}\right)$ with a percentage of $73.2 \%$ followed by iron in the form of iron oxide $\left(\mathrm{Fe}_{2} \mathrm{O}_{3}\right)$ with a percentage of $10.2 \%$. The lowest percentage obtained was attributed to thorium with a percentage of $0.01 \%$.

The elemental composition of FAC was determined both after carbonization and activation. There was a substantial decreasein aluminium percentage from $73.2 \%$ to $32.5 \%$ after carbonization. This was attributed to the releasing of $40.7 \%$ of aluminium under heating at $800{ }^{\circ} \mathrm{C}$. Indeed, some aluminium particles interact with carbon ofraw material to form tar or carbonaceous gas such as $\mathrm{CO}$ or $\mathrm{CO}_{2}$. This interaction can remove Al particles, acting as catalyst for vapor formation.

Furthermore, the concentration of the iron element increased noticeably. This was due to the activation of the precursor with iron salt $\left(\mathrm{FeCl}_{3}\right)$. This result confirmed the hypothesis that iron is present on the surface of FAC after carbonization. This result was similar to those obtained by XRD and FTIR. It was also observed that, after carbonization, there was a general increase in the concentrations of other species. This could have been due to the fact that with increasing temperature, the release organic matter led to adecreasein mass of the carbon element. Nevertheless, the mass of inorganic elements is quasi-static, because it is well knowthat almost all inorganic elements can be crackedat high temperature. Hence, the mass loss of carbon will lead to the increase of mass in the inorganic elements of the sample.

Functional group analysis of the CP and FAC samples
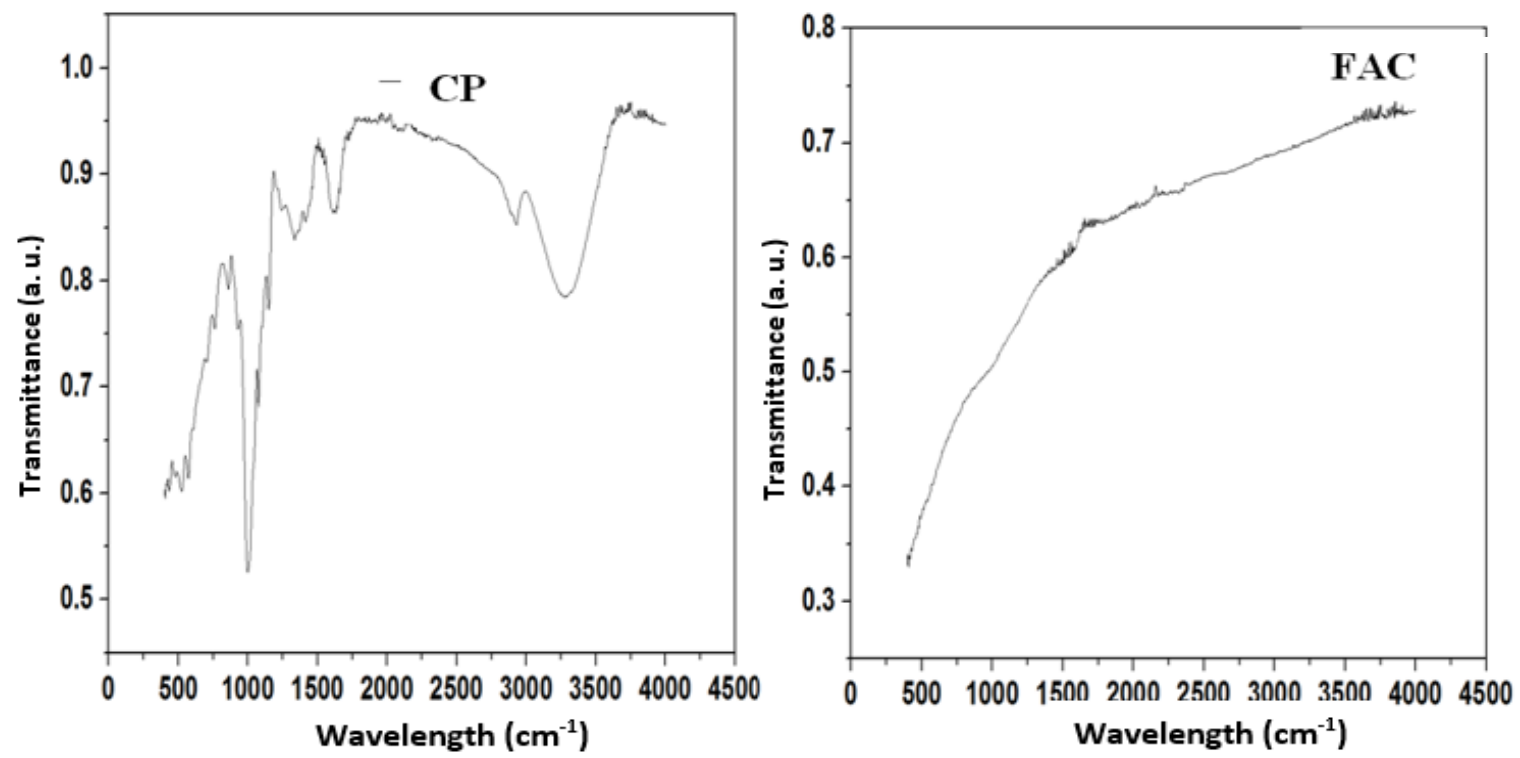

Fig. 3. FTIR spectrum of CP and Spectrum of FAC

The FTIR spectra of the CP revealed the presence of a broad band between 3050 and $3200 \mathrm{~cm}^{-1}$ corresponding to the stretching vibration of $-\mathrm{OH}$ of the oxygenated functional groups and water molecules adsorbed. The peak located at $2855 \mathrm{~cm}^{-1}$ was attributed to the stretching vibration of $-\mathrm{CH}_{2}-$ of the alkyl group. The bands located at $1715 \mathrm{~cm}^{-1}, 1455 \mathrm{~cm}^{-1}$, and $1261 \mathrm{~cm}^{-1}$ correspond to the vibration $-\mathrm{C}=\mathrm{O}$ of aldehyde, $\mathrm{C}=\mathrm{C}$ of aromatic ring, and- $\mathrm{C}-\mathrm{O}$ of alcohol, respectively. The peaks located at $1000 \mathrm{~cm}^{-1}, 822$ $\mathrm{cm}^{-1}$ and $744 \mathrm{~cm}^{-1}$ correspond to the bending vibration of the $-\mathrm{C}-\mathrm{O}$ and to the stretching 
vibration of $\mathrm{C}-\mathrm{H}$ of the meta and para-di-substituted aromatic compounds, respectively. Finally, the two peaks observed at $517 \mathrm{~cm}^{-1}$ and $551 \mathrm{~cm}^{-1}$ correspond to the K-O vibration (Dizge et al. 2008; Hui et al. 2009; Deshuai et al. 2013; Lknur et al. 2015; Sayğılıand Guzel 2016; Lékéné et al. 2018).

On the FAC spectrum (Fig. 3b), it was observed that all the bands observed on the precursor disappeared. Only the bands at 810 and $1557 \mathrm{~cm}^{-1}$ attributed to the stretching vibration of $\mathrm{Fe}-\mathrm{O}-\mathrm{Fe}$ bonds of iron oxide both for magnetite and maghemite and $-\mathrm{C}=\mathrm{C}$ of aromatic ring, respectively, were revealed. The calcinations of the raw material compound led to the aromatization of carbon present in the precursor through the DielsAlder reaction, which led to the disappearance of oxygenated groups between 290 and $350{ }^{\circ} \mathrm{C}$. This phenomenon was due to the oxidation of some surface functionnal groups of raw material due to the carbonization or the increase in temperature. Another reason was that the surface of carbonaceous material formed after carbonization was well covered by iron oxide. This result coupled with the thermal analysis can explain why all the peaks observed at first on the precursor spectrum no longer appeared on the FTIR spectra of FAC sample.

\section{XRD of CP and FAC samples}
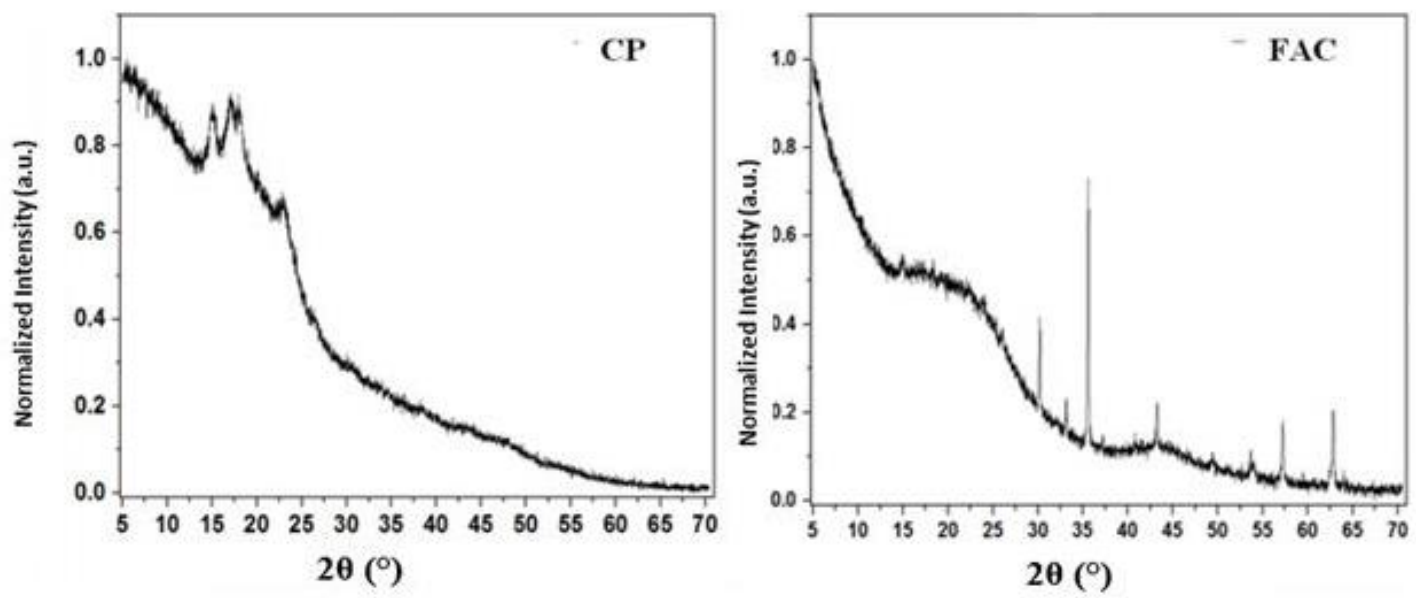

Fig. 4. XRD of $\mathrm{CP}$ and $\mathrm{FAC}$

The X-ray diffractograms of CP and FAC are presented in Fig. 4. The diffused haloes (imperfect developing of photographs) appearing at $2 \theta$ values between $5^{\circ}$ to $70^{\circ}$ confirmed the absence of any ordered crystalline structure, indicative of the amorphous nature of material having some degree of non-arrangement in the molecular chain, which is an advantageous property for well-defined adsorbents. In a previous study (Rajeshwari et al. 2010), the X-ray diffraction studies of most of the raw materials indicated a relatively highly disordered structure. This entails the best material for the production of activated carbon (Cheol-Min and Katsumi 2002). The spectrum of FAC indicated six main crystallization peaks of a magnetite-maghemite mixture at $30.08^{\circ}, 35.50^{\circ}, 43.15^{\circ}$, $53.38^{\circ}, 57.07^{\circ}$, and $62.81^{\circ}$, which correspond to (220), (311), (400), (422), (511), and (440) diffraction planes respectively (Wang et al. 2009; Kim 2015; Miranda et al. 2015). The carbonization temperature used during the preparation of the FAC makes it possible to obtain a mixture of magnetite and maghemite, since it is not the main factor for particle growth of pure maghemite but instead the composition of the compound (Birsan 
et al. 2007; Marques Neto et al. 2017). Moreover, because growth occurs on a carbon surface, especially on the surface of activated carbon, the speed of transformation of magnetite into maghemite decreases, as Birsan and co-workers (2007) demonstrated in their work. Indeed, transformation of magnetite into maghemite occurs exactly at $330{ }^{\circ} \mathrm{C}$. The presence of carbon does not allow the total transformation of magnetite into maghemite (Boguslavsky and Margel 2008) because the quantity of magnetite transformation depends on the composition of the compound (Birsan et al. 2007). Since FAC is the combination of carbon and iron oxide, the complete transformation of magnetite to maghemite becomes very difficult. The maghemite and magnetite are approved for their magnetic property, in particular, magnetite is ferromagnetic (Oliveira et al. 2002; Mbaye 2015). Magnetite is a natural magnet and is the most magnetic of all the minerals on earth (Mènager et al. 2004).

pH of zero-point charge $\left(\mathrm{pH}_{z p c}\right)$ of FAC

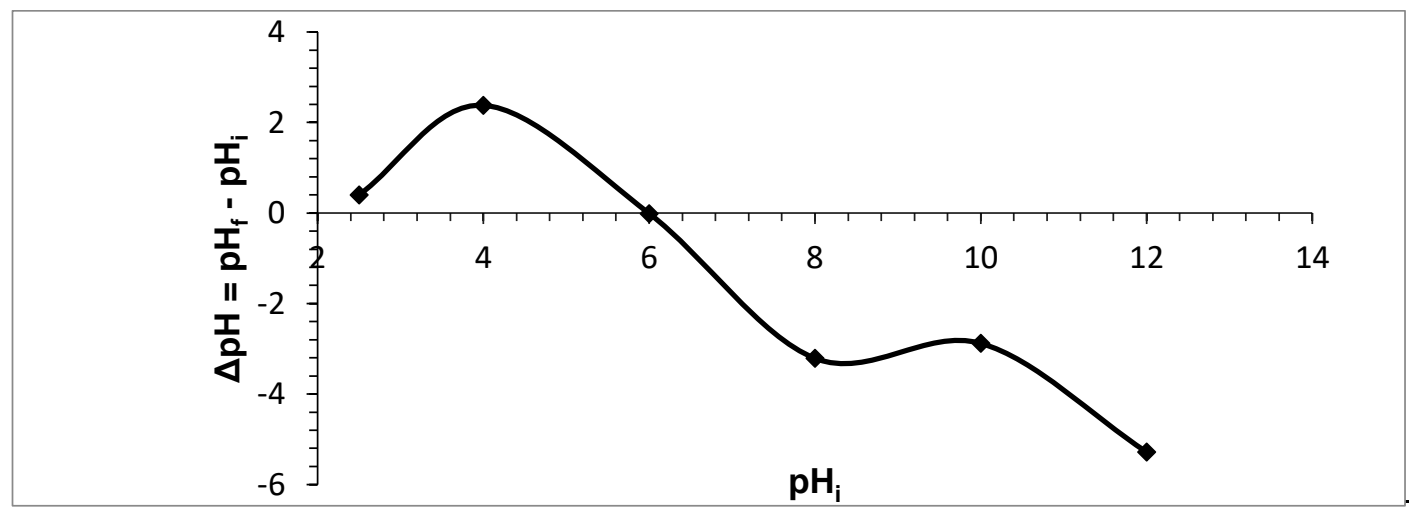

Fig. 5. The graph of the determination of point of zero charge $\left(\mathrm{pH}_{\mathrm{pzc}}\right)$

Based on the results in (Fig. 5), the prepared FAC had a $\mathrm{pH}_{\mathrm{zpc}}$ of 5.9. This suggested that when the $\mathrm{pH}$ of the solution was less than 5.9, the surface material carried total positive charges, which implicated that the number of functional groups with one or more atoms in positive form was predominant. Meanwhile, if the $\mathrm{pH}$ was greater than 5.9, the surface of the material had more negatively charged atoms and the total charges on the surface became negative. Furthermore, if the $\mathrm{pH}$ is close or equal to 5.9, there will be no charge on the surface: there are then more positive charges than negative charges (Slasli 2002). Similar results were obtained by Hui et al. (2009). 
Specific surface area and pore structure of CP and FAC samples
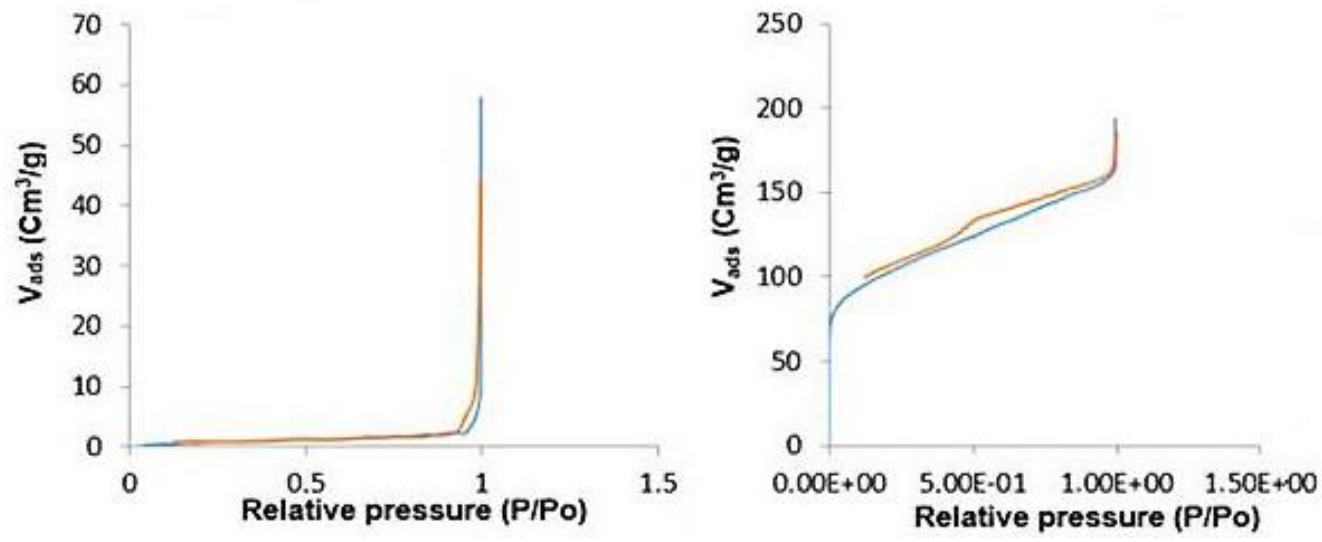

Fig. 6a. Nitrogen adsorption isotherm of CP

Fig. 6b. Nitrogen adsorption isotherm of FAC

Table 3.Textural Properties of the CP and FAC

\begin{tabular}{|c|c|c|}
\hline Adsorbents & CP & FAC \\
\hline Specific Surface Area BET $\left(\mathrm{m}^{2} / \mathrm{g}\right)$ & 2.497 & 405.890 \\
\hline average Pore diameter $(\mathrm{nm})$ & - & 4.067 \\
\hline Cumulative Pore Volume $\left(\mathrm{cm}^{3} / \mathrm{g}\right)$ & 0.004 & 0.108 \\
\hline
\end{tabular}

The nitrogen adsorption isotherm of the raw material (Fig. 6a) was type II, which is characteristic of non-porous or slightly porous materials. By contrast for FAC (Fig. $6 \mathrm{~b}$ ), the adsorption isotherm was type IV, which is associated with mesoporous materials (Youssef et al. 2005; Zhu et al. 2016). The specific surface area of CP and FAC were $2.50 \mathrm{~m}^{2} / \mathrm{g}$ and $405.9 \mathrm{~m}^{2} / \mathrm{g}$, respectively. Moreover, the total pore volume of the $\mathrm{CP}$ was weak $\left(0.004 \mathrm{~cm}^{3} / \mathrm{g}\right)$, which was in accordance with the type II isotherm.

Surface morphologies of the CP and FAC samples
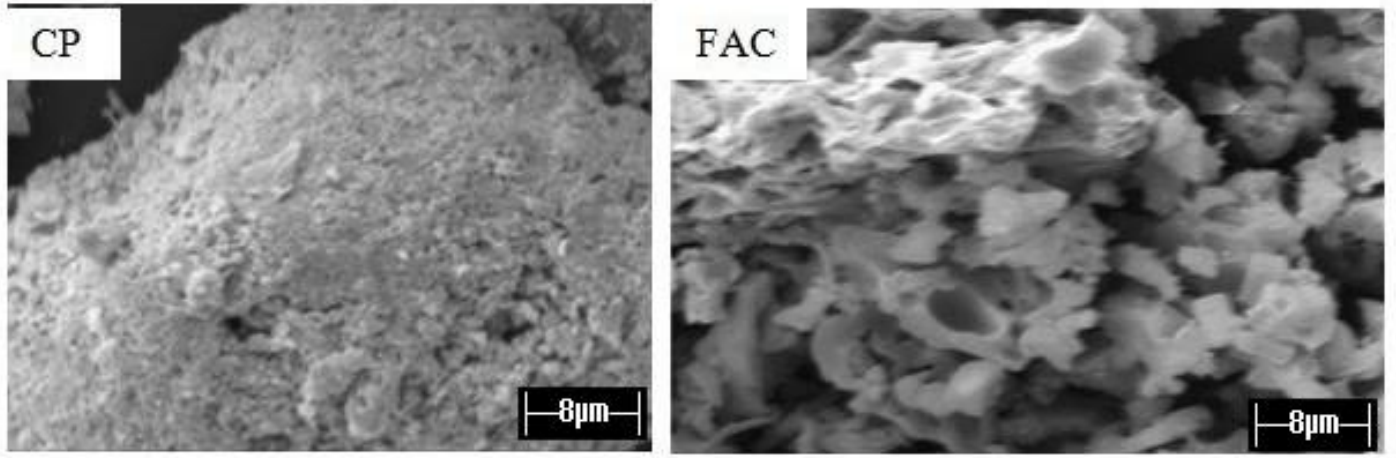

Fig. 7. SEM images of $\mathrm{CP}$ and FAC

Figure 7 shows the SEM images of the precursor $\mathrm{CP}$ and FAC, respectively, obtained under the optimum preparation conditions. Figure 7 shows that there were few 
pores available on the surface of the raw material due to agglomeration of CP particles. The SEM image of FAC shows that the chemical activation process was effective in creating well-developed pores on the surface of the FAC, leading to activated carbon with large surface area and porous structure compared to the precursor. A micrograph of the FAC material revealed a mixed porosity of micro-meso-pores as confirmed by its pore volume in Table 3. This result was in agreement with those obtained by the iodine and methylene blue numbers, which indicate a favorable presence of both micro and mesopores.

\section{Characterization of magnetic properties of FAC using a permanent magnet}

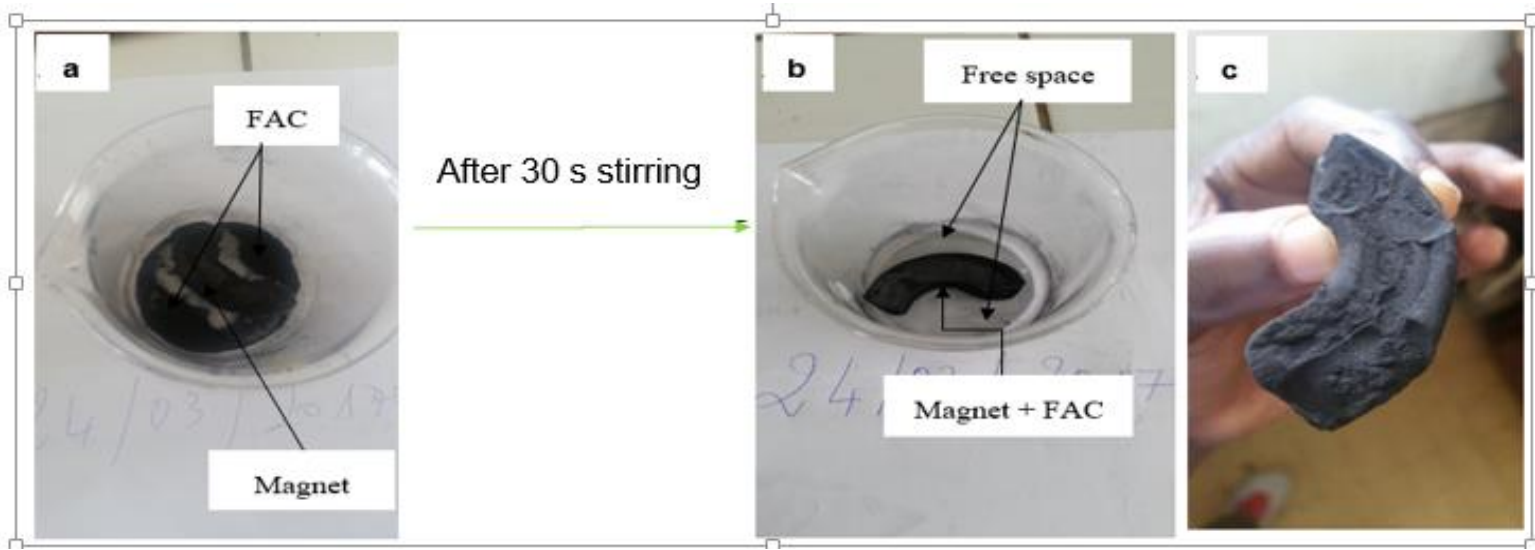

Fig. 8. Activity of the FAC

Ferromagnetic activated carbon was poured in a beaker; a magnet was brought in contact with it, as shown in Fig. 8a. As observed in the second beaker (Fig. 8b), the particles were displaced along the interior surface toward the magnet of the beaker (Fig. $8 \mathrm{~b})$. It was also observed that almost all of the FAC was retained by the magnet, which constitutes a qualitative indicator of magnetization of FAC (Mbaye 2015).

\section{CONCLUSIONS}

Ferromagnetic activated carbon (FAC) prepared from agricultural waste cassava peel was obtained by chemical activation using iron(III) chloride. The effect of carbonization temperature on textural and surface properties was studied.

1. The specific surface area of the prepared FAC was obtained by nitrogen adsorption as $405.9 \mathrm{~m}^{2} / \mathrm{g}$ and a total pore volume of $0.108 \mathrm{~cm}^{3} / \mathrm{g}$.

2. X-ray diffraction and magnetic activity showed that activated carbon prepared from cassava peel (CP) when activated by $\mathrm{FeCl}_{3}$ was ferromagnetic; SEM analysis of the FAC material revealed porosity, consistent with the presence of mesopores.

3. The experimental results indicated that this method of preparation of FAC was easy, convenient, and economical. The obtained FAC had good physico-chemical and structural properties. Therefore, agricultural wastes, particularly cassava peel, can be an alternative source or the production of activated carbon. 


\section{ACKNOWLEDGMENTS}

The authors are thankful to all of the members of the "Adsorption and Surface" Research group, at the Applied Physical and Analytical Chemistry Laboratory of University of YaoundéI. They also thank the Institute of Inorganic Chemistry, ChristianAlbrechts University of Kiel, and the laboratory for sensors, the Department of Microsystems Engineering-IMTEK, and the University of Freiburg, Germany for the analysis.

\section{REFERENCES CITED}

Agbor, E., Brauman, A., Griffon, D., and Trèche, S. (1995). "Importance du manioc en alimentation humaine dans différentes régions du monde [Importance of cassava as human food in different regions of the world]," in: Alimentl Transformation of Cassava Orstom, ORSTOM Edition, Paris, France, pp. 234-243.

Ahmedna, M., Marshall, W. E., and Rao, R. M. (2000). "Production of granular activated carbons from select agricultural by-products and evaluation of their physical, chemical and adsorption properties," Bioresource Technology 71(2), 113-123. DOI: 10.1016/S0960-8524(99)00070-X

Altenor, S., Carene, B., Emmanuel, E., Lambert, J., Ehrhardt, J. J., and Gaspard, S. (2009). "Adsorption studies of methylene blue and phenol onto vetiver roots activated carbon prepared by chemical activation," Journal of Hazardous Materials 165(1-3), 1029-1039. DOI: 10.1016/j.jhazmat.2008.10.133

ASTM D2866-11 (2018). "Standard test method for total ash content of activated carbon," ASTM International, West Conshohocken, PA, USA.

ASTM D5832-98 (2004). "Standard test method for volatile matter content of activated carbon," ASTM International, West Conshohocken, PA, USA.

Birsan, C., Predoi, D., and Andronescu, E. (2007). "IR and thermal studies of iron oxide nanoparticles in bioceramic matrix," Journal of Optoelectronics and Advanced Materials 9(6), 1821-1824.

Boguslavsky, Y., and Margel, S. (2008). "Synthesis and characterization of poly (divinylbenzene) coated magnetic iron oxide nanoparticles as precursor for the formation of air stable carbon coated iron crystalline nanoparticles," Journal Colloid and Interface Science 317(1), 101-114. DOI: 10.1016/j.jcis.2007.09.014

Budinova, T., Ekinci, E., Yardım, F., Grimm, A., Björnbom, E., Minkova, V., and Goranova, M. (2006). "Characterization and application of activated carbon produced by $\mathrm{H}_{3} \mathrm{PO}_{4}$ and water vapor activation," Fuel Processing Technology 87(10), 899-905. DOI: 10.1016/j.fuproc.2006.06.005

Caturla, F., Molina-Sabio, M., and Rodriguez-Reinoso, F. (1991). "Preparation of activated carbon by chemical activation with $\mathrm{ZnCl}_{2}$," Carbon 29(7), 999-1007. DOI: 10.1016/0008-6223(91)90179-M

Cheol-Min, Y., and Katsumi, K. (2002). "Adsorption properties of iodine-doped activated carbon fiber," Journal of Colloid and Interface Science 246(1), 34-39. DOI: 10.1016/jcis.2001.8012

Deshuai, S., Zhongyi, Z., Mengling, W., and Yude, W. (2013). "Adsorption of reactive dyes on activated carbon developed from Enteromorpha prolifera," American Journal of Analytical Chemistry 4(7), 17-26. DOI: 10.4236/ajac.2013.47A003 
Dizge, N., Aydiner, C., Demirbas, E., Kobya, M., and Kara, S. (2008). "Adsorption of reactive dyes from aqueous solutions by fly ash: Kinetic and equilibrium studies," Journal of Hazardous Materials 150(3), 737-746. DOI: 10.1016/j.jhazmat.2007.05.027

Duan, X. H., Srinivasakannan, C., Peng, J. H., Zhang, L. B., and Zhang, Z. Y. (2011). "Preparation of activated carbon from Jatropha hull with microwave heating: Optimization using response surface methodology," Fuel Processing Technology 92(3), 394-400. DOI: 10.1016/j.fuproc.2010.09.033

Girods, P., Dufour, A., Fierro, V., Rogaume, Y., Rogaume, C., Zoulalian, A., and Celzard, A. (2009). "Activated carbons prepared from wood particle board wastes: Characterization and phenol adsorption capacities," Journal of Hazardous Materials 166(1), 491-501. DOI: 10.1016/j.jhazmat.2008.11.047

Guler, C., Copur, Y., and Cihat, T. (2007). "The manufacture of particle boards using mixture of peanut hull (Arachis hypoqaea L.) and European black pine (Pinus nigra Arnold) wood chips," Bioresource Technology 99(8), 2893-2897. DOI: 10.1016/j.jbiortech.2007.06.013

Hameed, B. H., Ahmed, A. L., and Latiff, K. N. A. (2007a). "Adsorption of basic dye (methylene blue) onto activated carbon prepared from rattan sawdust," Dyes and Pigments 75(1), 143-149. DOI: 10.1016/j.dyepig.2006.05.039

Hameed, B. H., Din, A. T. M., and Ahmed, A. L. (2007b). "Adsorption of methylene blue onto bamboo-bossed activated carbon: Kinetics and equilibrium studies," Journal of Hazardous Materials 141(3), 819-825. DOI: 10.1016/j.jhazmat.2006.07.049

Hanen, N., and Abdelmottaleb, O. (2013). "Modeling of the dynamics adsorption of phenol from an aqueous solution on activated carbon produced from olive stones," Chemical Engineering and Process Technology 4(3), 1-7. DOI: 10.4172/2157-7048.1000153

Hesas, R. H., Arami-Niya, A., Wan Daud, W. M. A., and Sahu, J. N. (2013). "Preparation and characterization of activated carbon from apple waste by microwave-assisted phospheric acid activation: Application in methylene blue adsorption," BioResources 8(2), 2950-2966. DOI: 10.15376/biores.8.2.2950-2966

Hui, D., Le, Y., Guanghui, T., and Jiulei, D. (2009). "Preparation and characterization of activated carbon from cotton stalk by microwave assisted chemical activation application in methylene blue adsorption from aqueous solution," Journal of Hazardous Materials 166(2-3), 1514-1521. DOI: 10.1016/j.jhazmat.2008.12.080

Ioannidou, O., and Zabaniotou, A. (2007). "Agricultural residues as precursors for activated carbon production," Renewable and Sustainable Energy Reviews 11(9), 1966-2005. DOI: 10.1016/j.rser.2006.03.013

Jaguaribe, E. F., Medeiros, L. L., Barreto, M. C. S., and Araujo, L. P. (2005). "The performance of activated carbons from sugarcane bagasse, babassu, and coconut shells in removing residual chlorine," Brazilian Journal of Chemical Engineering 22(1), 41-47. DOI: 10.1590/S0104-66322005000100005

Kailappan, R., Gothandapani, L., and Viswanathan, R. (2000). "Production of activated carbon from prosopis (Prosopis juliflora)," Bioresource Technology 75(3), 241-253. DOI: 10.1016/S0960-8524(00)00056-0

Kouotou, D., Horace, N. M., Abdelaziz, B., Abdelrani, Y., and Ketcha, M. J. (2013a). "Optimization of activated carbons prepared by $\mathrm{H}_{3} \mathrm{PO}_{4}$ and steam activation of oil palm shells," Journal of Chemistry 2013, article number 654343. DOI: 10.1155/2013/654343

Kouotou, D., Ngomo, M. H., Baçaoui, A., Yaacoubi, A., and Ketcha, M. J. (2013b). "Physicochemical activation of oil palm shells using response surface methodology: Opti- 
mization of activated carbons preparation," International Journal of Current Research 5(3), 431-438. DOI: 10.1155/2013/654343

Kunquan, L., Zheng, Z., Xingfa, H., Guohua, Z., Jingwei, F., and Jibiao, Z. (2009).

"Equilibrium, kinetic and thermodynamic studies on the adsorption of 2-nitroaniline onto activated carbon prepared from cotton stalk fiber," Journal of Hazardous Materials 166(1), 213-220. DOI: 10.1016/j.jhazmat.2008.11.007

Lékéné, R. B. N., Nsami, J. N., Rauf, A., Kouotou, D., Belibi, P. D. B., Bhanger, M. I., and Mbadcam, J. K. (2018). "Optimization conditions of the preparation of activated carbon based egusi (Cucumeropsis mannii naudin) seed shells for nitrate ions removal from wastewater," American Journal of Analytical Chemistry 9(10), 439463. DOI: 10.4236/ajac.2018.910034

Lima, I. M., and Marshall, W. E. (2005). "Granular activated carbons from broiler manure: Physical, chemical and adsorptive properties," Bioresource Technology 96, 699-706. DOI: 10.1016/j.biortech.2004.06.021

Lknur, D., Canan Aydın, S., and Hakan, D. (2015). "Production and characterization of activated carbons from pumpkin seed shell by chemical activation with $\mathrm{ZnCl}_{2}$," Desalination and Water Treatment 57(6), 2446-2454. DOI: 10.1080/19443994.2015.1027276

Marques Neto, J. O., Bellato, C. R., de Souza, C. H. F., da Silva, R. C., and Rocha, P. A. (2017). "Synthesis, characterization and enhanced photocatalytic activity of iron oxide/carbon nanotube/Ag-doped $\mathrm{TiO}_{2}$ nanocomposites," Journal of the Brazilian Chemical Society 28(12), 2301-2312. DOI:10.21577/0103-5053.20170081.

Mbaye, G. (2015). Développement de Charbon Actif à Partir de Biomasses Lignocellulosiques Pour des Applications Dans le Traitement de L'eau[Development of Activated Carbon From Lignocellulosic Biomass in Application of Water Treatment], Doctoral Thesis, International Institute of Water and Environment Engineering, Ouagadougou, Bourkina Faso.

Mènager, C., Sandre, O., Mangili, J., and Cabruil, V. (2004). "Preparation and swelling of hydrophilic magnetic microgel," Polymer 45(8), 2475-2481. DOI: 10.1016/j.polymer.2004.02.018

Miranda, L. D. L., Bellato, C. R., Milagres, J. L., Moura, L. G., Mounteer, A. H., and Almeida, M. F. (2015). "Hydrotalcite $-\mathrm{TiO}_{2}$ magnetic iron oxide intercalated with the anionic surfactant dodecylsulfate in the photocatalytic degradation of methylene blue dye," Journal of Environment Management 156, 225-235. DOI:

10.1016/j.jenvman.2015.03.051

Ndi, N. J., and Ketcha, M. J. (2013). "The adsorption efficiency of chemically prepared activated carbon from cola nut shells by $\mathrm{ZnCl}_{2}$ on methylene blue," Journal of Chemistry 2013, Article ID 469170. DOI: 10.1155/2013/469170

Ndi, N. J., Ketcha, M. J., Anagho, G. S., Ghogomu, N. J., and Belibi, B. P. (2014). "Physical and chemical characteristics of activated carbon prepared by pyrolysis of chemically treated cola nut (Cola acuminata) shells wastes and its ability to adsorb organics," International Journal of Advanced Chemical Technology 3(1), 1-13. DOI: 10.9734/CSJI/2018/43411

Okibe, F. G., Ajibola, V. O., and Ndukwe, I. G. (2013). "Preparation and surface characteristics of activated carbon from Brachystegia eurycoma and Prosopis africana seed hulls," International Journal of Chemical Technology Research 5(4), 1991-2002. DOI: 10.3303/CET1437121 
Oliveira, L. C. A., Rio, V. R. A., and Fabris, J. D. (2002). "Activated carbon/ iron oxide magnetic composites for the adsorption of contaminants in water," Carbon 40(12), 2177-2183. DOI: 10.1016/S0008-6223(02)00076-3

Pelekani, C., and Snoeyink, V. L. (2000). "Competitive adsorption between atrazine and methylene blue on activated carbon: The importance of pore size distribution," Carbon 38(10), 1423-1436. DOI: 10.1016/S0008-6223(99)00261-4

Rajeshwari, S., Venckatesh, R., and Sangeetha, G. (2010). "Preparation and characterization of activated carbons from parthenium biomass by physical and chemical activation techniques," Engineering Journal of Chemistry 7(4), 1314-1319. DOI: $10.1155 / 2010 / 948015$

Sayğılı, H., and Guzel, F. (2016). "High surface area mesoporous activated carbon from tomato processing solid waste by zinc chloride activation: Process optimization, characterization and dyes adsorption," Journal of Cleaner Production 113, 995-1004. DOI: $10.1016 /$ j.jclepro.2015.12.055

Sing, H. P., Raizada, P., Pathania, D. G., and Sharma, P. (2013). "Microwave induced $\mathrm{KOH}$ activation of guava peel carbon as an adsorbent for congo red dye removal from aqueous phase," Indian Journal Chemical Technology 20(5), 305-311.

Slasli, M. A. (2002). Modélation de L'adsorpton par les Charbons Microporeux: Approaches Théorique et Expérimentale[Modelization of Adsorption by Microporous Activated Carbon: Theoretical and Experimental Approach], Ph.D. Dissertation, Université Neuchatel, Neuchatel, Switzerland.

Sudaryanto, Y., Hartono, S. B., and Ismadji, S. (2006). "High surface area activated carbon prepared from cassava peel by chemical activation," Bioresource Technology 97(5), 734739. DOI: 10.1016/j.biortech. 2005.04.029

Tan, I. A. W., Ahmad, A. L., and Hameed, B. H. (2008). "Preparation of activated carbon from coconut husk: Optimization study on removal of 2, 4, 6-trichlorophenol using response surface methodology," Journal of Hazardous Materials 153(1-2), 709-717. DOI: 10.1016/j.jhazmat.2007.09.014

Tounsadi, H., Khalidi, A., Abdennouri, M., and Barka, N. (2016). "Activated carbon from Diplotaxis harra biomass: Optimization of preparation conditions and heavy metal removal," Journal of the Taiwan Institute of Chemical Engineers 59, 348-358. DOI:10.1016/j.jtice.2015.08.014.

Youssef, A. M., Radwan, N. R. E., Abdel-Gawad, I., and Singer, G. A. A. (2005). "Textural properties of activated carbons from apricot stones," Colloids and Surfaces 252(2-3), 143-151. DOI: 10.1016/j.colsurfa.2004.09.008

Zhu, G.-z., Deng, X.-1., Hou, M., Sun, K., Zhang, Y.-p., Li, P., and Liang, F.-m. (2016). "Comparative study on characterization and adsorption properties of activated carbons by phosphoric acid activation from corncob and its acid and alkaline hydrolysis residues," Fuel Processing Technology 144, 255-261. DOI:

10.1016/j.fuproc.2016.01.007

Article submitted: May 30, 2019; Peer review completed: November 17, 2019; Revised version received: January 20, 2020; Published: February 3, 2020.

DOI: 10.15376/biores.15.2.2133-2146 